
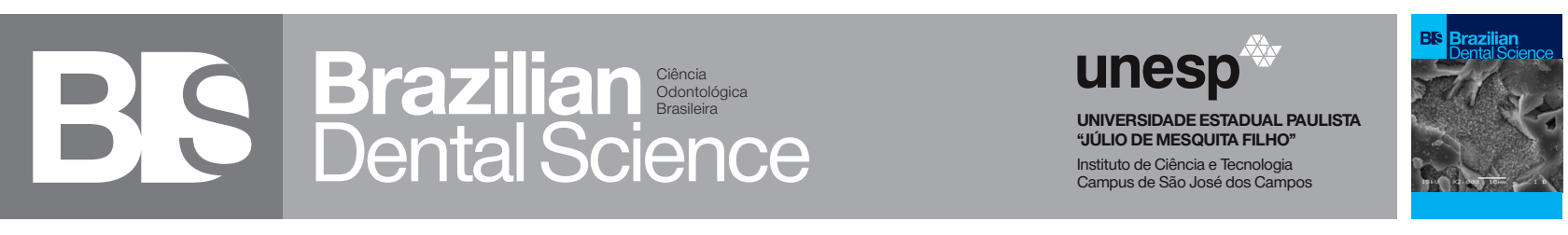

\title{
Bond strength to ZLS ceramics at different etching times and cementation protocols after aging
}

Influência da cimentação e da termociclagem na resistência de união da cerâmica de silicato de lítio reforçada com zircônia

Kevelin Poliana Palma Rigo THIESEN ${ }^{1}$, Maria Daniela Basso de SOUZA ${ }^{1}$, Vera Lucia SCHMITT ${ }^{1}$, Flávia Pardo Salata NAHSAN ${ }^{2}$, Fabiana Scarparo NAUFEL ${ }^{1}$

1 - Department of Restorative Dentistry - State University of Western Paraná - Cascavel - PR - Brazil.

2 - Department of Dentistry - Federal University of Sergipe - Aracaju - SE - Brazil.

\section{ABSTRACT}

Objective: To assess the influence of $5 \%$ hydrofluoric acid etching time (ET), cementation protocol (CP), and thermal cycling (TC) aging on the microshear bond strength ( $\mu \mathrm{SBS}$ ) of zirconiareinforced lithium silicate ceramic (ZLS) to adhesive resin cement. Material and Methods: Ten VITA Suprinity ${ }^{\circledR}$ ceramic blocks were cut in 120 slices ( $1.4 \mathrm{~mm}$ thickness) and randomly assigned to 12 groups ( $n=10$ ) according to the combination of factors ( $2 \times 3 \times 2$ design): etching time (20 or $30 \mathrm{~s}$ ), cementation protocol (silane + universal adhesive + resin cement; universal adhesive + resin cement; silane + resin cement) and thermal cycling (cycled or no-cycled). RelyX Ceramic Primer and Scotchbond ${ }^{\text {тм }}$ Universal Adhesive were used respectively as silane (S) and universal adhesive (Ua). Ceramic surface was etched, and the cementation protocol performed on the delimited bonding area. Then, resin cement (RelyX $^{\mathrm{TM}}$ Ultimate Cement [Rc]) cylinders were bonded and light cured. After, specimens were stored in deionized water at $37^{\circ} \mathrm{C}$ for 7 days and subjected to the $\mu$ SBS test. Results: Data passed the normality test and three-way ANOVA analysis showed statistical difference $(\mathrm{p}<0.01)$ for isolated; double (ET/TC) ( $<<0.05)$, and triple $(p<0.05)$ factor interactions. Conclusion: The combination 30s etching-Ua-Rc presented higher adhesive bond strength after thermal aging.

\section{KEYWORDS}

Adhesive; Ceramics; Hydrofluoric acid; Resin cements.

\section{RESUMO}

Objetivo: Avaliar a influência do tempo de condicionamento comácidofluorídrico 5\% (ET), protocolo de cimentação (CP), e envelhecimento por termociclagem (TC) na resistência de união ao microcisalhamento ( $\mu \mathrm{SBS}$ ) da cerâmica de silicato de lítio reforçada com zircônia (ZLS) ao cimento resinoso adesivo. Material e Método: Dez blocos da cerâmica VITA Suprinity® foram cortados e 120 fatias (com espessura de $1,4 \mathrm{~mm})$ e distribuídos aleatoriamente em 12 grupos $(\mathrm{n}=10)$ de acordo com o fator de combinação ( $2 \times 3 \times 2)$ : tempo de condicionamento (20 ou 30 s), protocolo de cimentação (silano + adesivo universal + cimento resinoso; adesivo universal + cimento resinoso; silano + cimento resinoso) e ciclagem térmica (ciclado ou não-ciclado). RelyX Ceramic Primer e adesivo Scotchbond ${ }^{\mathrm{TM}}$ Universal foram utilizados respectivamente como silano (S) e adesivo universal (Ua). A superfície cerâmica foi condicionada e o protocolo de cimentação aplicado sobre área de cimentação delimitada. Portanto, cilindros de cimento resinoso (cimento RelyX ${ }^{\mathrm{TM}}$ Ultimate [Rc]) foram cimentados e fotopolimerizados. Após, os espécimes foram armazenados em água deionizada a $37^{\circ} \mathrm{C}$ por 7 dias e submetidos ao teste de $\mu$ SBS. Resultados: Após teste de normalidade, os dados foram analisados pelo teste ANOVA três critérios mostrando diferença estatística ( $\mathrm{p}<0.01$ ) para a análise do fator isolado; para a interação entre dois fatores (ET/TC) ( $\mathrm{p}<0.05)$, e interação entre os três fatores ( $\mathrm{p}<0.05$ ). Conclusão: A combinação 30s de condicionamento-Ua-Rc apresentou a maior resistência de união adesiva após a ciclagem térmica.

\section{PALAVRAS-CHAVE}

Adesivo; Cerâmica; Ácido fluorídrico; Cimento resinoso. 


\section{INTRODUCTION}

D ental ceramics are widely used as aesthetic restorative material given the ability to simulate the natural teeth appearance [1] and their clinical success depends on the proper mechanical-chemical bond adhesion among resin cement (Rc), ceramic (C) and tooth substrate [2]. Moreover, the hydrofluoric acid (HF) etching is a necessary step to improve the Rc/glass-ceramic bond [1], allowed only for silica-based (SiO2) or glass-ceramics [3]. The HF selectively dissolves the glass matrix, exposes the crystalline content and makes the etched surface rough. As result, micromechanical retention is obtained [4].

After etching, the silane (S) application step [5] increases the chemical bond. By improving infiltration and cementing agent-C surface porosities contact [6], the polymer interconnections are favored [7]. It happens because S-bifunctional molecules allow the bonding between organic (Rc monomers) and inorganic (glass matrix ceramic silica content) compounds [8].

Along with the process of incorporating crystals to improve the mechanical properties of ceramics, a new generation of glass-ceramics was developed: Suprinity zirconia-reinforced lithium silicate (ZLS) ceramic. Furthermore, zirconia does not allow mechanical/chemical bond to Rc using $\mathrm{HF}$ and silane. To this end, a bifunctional organic molecule MDP (10-Methacryloyloxydecyl dihydrogen phosphate) monomer [9-11] is required: ester phosphate monomer bonds to the oxides (such as zirconia oxide) [12] and the other groups copolymerize with the resin matrix of cements. However, the chemical reactions formed between hydroxyl groups of the MDP monomer and those groups on the zirconia ceramic surface can be weakened after thermal cycling [10]. Besides, the different HF etching time protocols indicated by ZLS ceramic manufacturers (Vita Zahnfabrik; CELTRA Duo ceramic, Dentisply) brings up some uncertainties since it may directly influence the C-Rc bond strength $[4,13,14]$.
Recently, a new universal adhesive-resin cement $(\mathrm{Ua}+\mathrm{Rc}$ ) combination (resin cement RelyX $^{\mathrm{TM}}$ Ultimate $3 \mathrm{M} \quad$ ESPE; Scotchbond ${ }^{\mathrm{TM}}$ Universal 3M ESPE) recommended for glassceramic cementation presented good results for bond strength to zirconia after aging [11]. All the primers for indirect restorations, such as MDP, silane, and adhesive, compose that combination. Furthermore, the manufacturer assertion regarding possible protocols $[(\mathrm{S}+\mathrm{Rc})$; $(\mathrm{S}+\mathrm{Ua}+\mathrm{Rc}) ;(\mathrm{Ua}+\mathrm{Rc})]$ to be applied is still under question.

The lack of evidence about the relationship among of 20 or $30 \mathrm{~s}$ HF etching, distincts cementation protocols as well thermal cycling on the microshear bond strength ( $\mu$ SBS) of Suprinity ZLS ceramic prompted this study. Therefore, to elucidate such effects, we hypothesized that (1) different etching times, (2) cementation protocol, and (3) thermal cycling affect the $\mu$ SBS.

\section{MATERIAL AND METHODS}

Ten rectangular ZLS ceramic (Suprinity; Vita Zahnfabrik, Bad Säckingen, Germany, shade HT 0M1) blocks (18 x 14 x $12 \mathrm{~mm}$ ) were vertically cut into 120 slices ( $12 \times 7 \times 1.4 \mathrm{~mm})$ using a low-speed cutting saw (Labcut 1010 extec, Enfield, USA) with diamond disc 3" x 0.006" x 0.5" (Lapmaster Wolters, Mt Prospect, IL, USA) under water irrigation. They were wetpolished with a 600-grit silicon carbide paper for 1 min with a rotational polishing device (Arotec PL4, São Paulo, Brazil) and crystallized according to manufacturer's instructions in a Vita Vacumat oven (Vita Zahnfabrik, Bad Säckingen, Germany). Then, the specimens were randomly assigned to twelve groups $(n=10)$ according to the combination of factors $(2 \times 3 \times 2$ design): etching time (20 or 30 seconds), cementation protocol (S+Ua+Rc; Ua+Rc; S+Rc), and thermal cycling (cycled, no-cycled) (Table 1). The materials used are shown on Table 2. A sample size of ten specimens was calculated considering minimum detectable difference in mean $\mu$ SBS of 5.0, standard deviation of 3.1, a-error level of 
$5 \%$ and $95 \%$ statistical power. The specimens were etched with 5\% HF (Condac porcelana, FGM, Joinville, SC, Brazil), rinsed with water (60 s) and dried with oil free compressed air (30 s). The delimitation of the ceramic surface bonding area was performed using an adhesive tape (Imperial, 3M, Sumare, Brazil) with four holes ( $1 \mathrm{~mm}$-diameter) positioned over it. Then, they received the following post etching surface treatments, according to the groups:

- Silane: two layer of a silane coupling agent (RelyX Ceramic Primer, 3M ESPE, St Paul, MN, USA) which were left in contact for 60 seconds and air-dried for 60 seconds.

- Universal adhesive: a thin layer of photoactivated universal adhesive (SBU-Scotchbond ${ }^{\mathrm{TM}}$ Universal 3M ESPE, 3M ESPE, St Paul, MN, USA) applied for 5 seconds with microbrush and the excess air-removed for $10 \mathrm{~s}$.

The resin cement (RXU- RelyX Ultimate, 3M ESPE, St. Paul, MN, USA) was carefully inserted by spatule into translucent Teflon tubes (Solidor Haryana, India) matrices to obtain cylinders $(2.0 \mathrm{~mm}$ height x $0.76 \mathrm{~mm}$ internal diameter). Then, each tube was positioned over the tape, ensuring the lumen coincided with the circular ceramic area exposed by the perfurtation [2] and light-cured (through the ceramic) for $40 \mathrm{~s}$ using a light-emitting diode (LED) device (Valo Cordless, standard mode; Ultradent Inc, South Jordan, UT, USA) with an output of $1,000 \mathrm{~mW} / \mathrm{cm}^{2}$.

The ceramic specimens were fixed with epoxy resin (Durepoxi, Loctite, Itapevi, SP, Brazil) to acrylic resin filled PVC rings and stored in deionized water for 7 days at 37o C. After $24 \mathrm{~h}$, the teflon tubes and tape were carefully removed to expose the four resin cement cylinders and specimens subjected to 10,000 thermal cycles (ERIOS 3700, São Paulo, $\mathrm{SP}$, Brazil) with water $\left(5{ }^{\circ} \mathrm{C}\right.$ to $\left.55^{\circ} \mathrm{C}\right)$ for $30 \mathrm{~s}$ dwell and $10 \mathrm{~s}$ transfer times.

For the microshear bond strength ( $\mu$ SBS) test, using a universal mechanical testing machine (EMIC DL2000, São José dos Pinhais, $\mathrm{PR}$, Brazil), a thin steel round wire $(0.2 \mathrm{~mm}$ diameter) was looped around each cylinder, aligned with the bonding interface. The shear load was applied at a crosshead speed of $1 \mathrm{~mm} /$ min until failure. The mean values of the four cylinders was recorded as the bond strength for each specimen, expressed in $\mathrm{MPa}$. The mean bond strength values of each group represented the mean of the 10 specimens. After confirmation of the normal (Shapiro-Wilk) and homogeneous (Cochran) distributions, the data from $\mu \mathrm{SBS}$ were submitted to three-way ANOVA, followed by the Tukey post hoc test $(\alpha=0.05)$ for multiple comparisons.

The failure mode of debonded specimens was determined at 100\% magnification using an optical microscopy (Dino-Lite Premier, Anmo Electronics Corporation, New Taipei City, Taiwan), and recorded as adhesive (interfacial failure), cohesive (within ceramic or within resin cement), or mixed (involving resin cement and ceramic).

Two representative specimens (A and B) of each etched group, after gold spraying via sputtering, were submitted to scanning electron microscopy (SEM) (JSM 5600 LV; JEOL, Pleasanton, CA, USA) analysis (500 $\mathrm{x}$ and $2,000 \mathrm{x}$ magnification and operated at $15 \mathrm{kV}$ ) to observe the ceramic surface morphology.

Table 1 - Group description

\begin{tabular}{|c|c|c|c|c|}
\hline & Group & $\begin{array}{l}\text { Etching } \\
\text { time }\end{array}$ & $\begin{array}{c}\text { Cementation } \\
\text { protocol }\end{array}$ & $\begin{array}{l}\text { Thermal } \\
\text { cycling }\end{array}$ \\
\hline G1 & 20SRc/C & \multirow{4}{*}{20 seconds } & \multirow{2}{*}{$\begin{array}{l}\text { silane + resin } \\
\text { cement }\end{array}$} & cycled \\
\hline G2 & 20SRc/no-C & & & no-cycled \\
\hline G3 & 20SUaRc/C & & \multirow{2}{*}{$\begin{array}{l}\text { silane + universal } \\
\text { adhesive + resin } \\
\text { cement }\end{array}$} & cycled \\
\hline G4 & 20SUaRc/no-C & & & no-cycled \\
\hline G5 & 20URc/C & & \multirow{2}{*}{$\begin{array}{l}\text { universal adhesive } \\
\text { + resin cement }\end{array}$} & cycled \\
\hline G6 & 20URc/no-C & & & no-cycled \\
\hline G7 & 30SRc/C & & \multirow{2}{*}{$\begin{array}{l}\text { silane + resin } \\
\text { cement }\end{array}$} & cycled \\
\hline G8 & 30SRc/no-C & & & no-cycled \\
\hline G9 & 30SUaRc/C & \multirow[t]{2}{*}{30 seconds } & \multirow{2}{*}{$\begin{array}{l}\text { silane + universal } \\
\text { adhesive + resin } \\
\text { cement }\end{array}$} & cycled \\
\hline G10 & 30SUaRc/no-C & & & no-cycled \\
\hline G11 & 30UaRc/C & & \multirow{2}{*}{$\begin{array}{l}\text { universal adhesive } \\
\text { + resin cement }\end{array}$} & cycled \\
\hline G12 & 30UaRc/no-C & & & no-cycled \\
\hline
\end{tabular}

(S) silane; (Ua) universal adhesive; (Rc) resin cement; (C) cycled; (no-C) no cycled. 
Table 2 - Manufacturers and composition of materials used in this study

\begin{tabular}{|c|c|c|}
\hline Material & Batch & Composition \\
\hline $\begin{array}{l}\text { Suprinity; VitaZahnfabrik, } \\
\text { Bad Säckingen, Germany }\end{array}$ & 51590 & $\begin{array}{l}\text { Silicon dioxide } 56-64 \% \text { in weight, lithium oxide } 15-21 \% \text { in weight, zirconia } 8-12 \% \text { in weight, and } \\
\text { others }>10 \% \text { in weight. }\end{array}$ \\
\hline Condac porcelana, FGM, Joinville, Brazil & & $5 \%$ hydrofluoric acid, water, thickener, tensioactive and coloring agents. \\
\hline $\begin{array}{l}\text { RelyX Ceramic Primer, 3M ESPE, St Paul, } \\
\text { MN, USA }\end{array}$ & N662908 & Ethyl alcohol, water, methacryloxypropyltrimethoxysilane \\
\hline $\begin{array}{l}\text { Scotchbond }{ }^{\mathrm{TM}} \text { Universal, 3M ESPE, St } \\
\text { Paul,MN, USA }\end{array}$ & 577056 & $\begin{array}{c}\text { MDP phosphate monomer, dimethacrylate, HEMA, Vitrebond }{ }^{\mathrm{TM}} \text { copolymer, alcohol, water, } \\
\text { primers, and silane }\end{array}$ \\
\hline $\begin{array}{l}\text { Relyx }{ }^{\text {TM }} \text { Ultimate, 3M ESPE, } \\
\text { St Paul, MN, USA }\end{array}$ & 579623 & $\begin{array}{c}\text { Base paste - methacrylate monomers, radiopaque silane loads, primers, stabilizers, and } \\
\text { rheological additives. } \\
\text { Catalyst paste - methacrylate monomers, radiopaque alkaline fillers, primers, stabilizers, } \\
\text { pigments, rheological additives, fluorescent coloring agents, dual Scotchbond }{ }^{\text {TM }} \text { Universal } \\
\text { adhesive activator. }\end{array}$ \\
\hline
\end{tabular}

Acronyms: MDP - 10-Methacryloyloxydecyl dihydrogen phosphate; HEMA - Hydroxyethyl methacrylate.

\section{RESULTS}

The $\mu$ SBS results are shown in Tables 3 and 4. The statistical analysis showed significant differences for the isolated factor $(p<0.01)$. When etching times were compared, 30 seconds was significantly higher than the other one $(\mathrm{p}<0.01)$. For the post etching treatment, no statistical difference was found among silanized, silanized/universal adhesive, and universal adhesive ( $p>0.05)$. The no-cycled groups showed significantly higher $\mu$ SBS mean values than those cycled $(\mathrm{p}<0.01)$. Statistical difference was found $(\mathrm{p}<0.05)$ for the etching time/thermal cycling interaction. The $20 \mathrm{sec} / \mathrm{cycled}$ group showed the lowest $\mu$ SBS mean value. For the triple interaction, significant differences were found $(\mathrm{p}<0.05)$. The $20 \mathrm{sec} / \mathrm{cycled} /$ silanized group showed the lowest $\mu$ SBS mean value. The greater $\mu$ SBS mean value was observed for the $30 \mathrm{sec} /$ no-cycled/universal adhesive.

Figure 1 shows the descriptive analysis of the failure modes. An adhesive failure predominance was detected for all groups, regardless the etching times or thermal cycling. Conversely, mixed failures (cohesive within resin cement) were found in groups (20SRc/C, 20SRc/no-C, 30SRc/no-C, 30SUaRc/no-C) but with lower incidence.
Figure 2, 3 and 4, SEM photomicrographs shows the ceramic surface morphology etched for two different etching times (20 and $30 \mathrm{~s}$ ).

Table 3 - Means of $\mu$ SBS $(\mathrm{MPa})( \pm \mathrm{SD})$ for the isolated factors and double interaction

\begin{tabular}{|c|c|c|}
\hline \multirow{2}{*}{ Thermal cycling } & \multicolumn{2}{|c|}{ Etching time } \\
\hline & 20 seconds & 30 seconds \\
\hline & $21.3 \pm 3.2 b$ & $24.9 \pm 3.5 \mathrm{a}$ \\
\hline cycled $(26.24 \pm 3.43) a$ & $26.1 \pm 3.1 \mathrm{aA}$ & $26.4 \pm 3.8 \mathrm{aA}$ \\
\hline no-cycled $(19.97 \pm 3.17) b$ & $16.5 \pm 3.2 \mathrm{bB}$ & $23.4 \pm 3.1 \mathrm{bA}$ \\
\hline
\end{tabular}

Superscript different letters indicate statistically significant differences for the isolated factor $(p<0.01)$. Different letters indicate statistically significant differences for the double interaction between the factors of etching time and thermal cycling $(p<0.05)$, considering lowercase letters for columns and capital letters for rows.

Table 4 - Means of $\mu$ SBS (MPa) $( \pm \mathrm{SD})$ for all groups

\begin{tabular}{|c|c|c|c|}
\hline \multirow{2}{*}{$\begin{array}{l}\text { Etching time } \\
\text { /Thermal } \\
\text { cycling }\end{array}$} & \multicolumn{3}{|c|}{ Cementation Protocol } \\
\hline & Silane & $\begin{array}{l}\text { Silane + } \\
\text { universal } \\
\text { adhesive }\end{array}$ & $\begin{array}{l}\text { Universal } \\
\text { adhesive }\end{array}$ \\
\hline $20 /$ no-cycled & $25.6 \pm 2.6 \mathrm{aA}$ & $26.6 \pm 2.7 \mathrm{aA}$ & $26.2 \pm 3.9 \mathrm{abA}$ \\
\hline $30 /$ no-cycled & $23.5 \pm 4.5 \mathrm{aB}$ & $26.7 \pm 2.7 \mathrm{aAB}$ & $28.8 \pm 4.1 \mathrm{aA}$ \\
\hline $20 /$ cycled & $13.8 \pm 3.8 \mathrm{bB}$ & $13.5 \pm 2.2 \mathrm{bB}$ & $22.2 \pm 3.7 \mathrm{bA}$ \\
\hline $30 /$ cycled & $22.2 \pm 4.5 \mathrm{aA}$ & $23.4 \pm 2.2 \mathrm{aA}$ & $24.7 \pm 2.7 \mathrm{abA}$ \\
\hline
\end{tabular}

Means followed by different lowercase letters in each column and upper capital letters in each rows differ statistically by Tukey's test at 5\%. 
Failure Mode Incidence \%

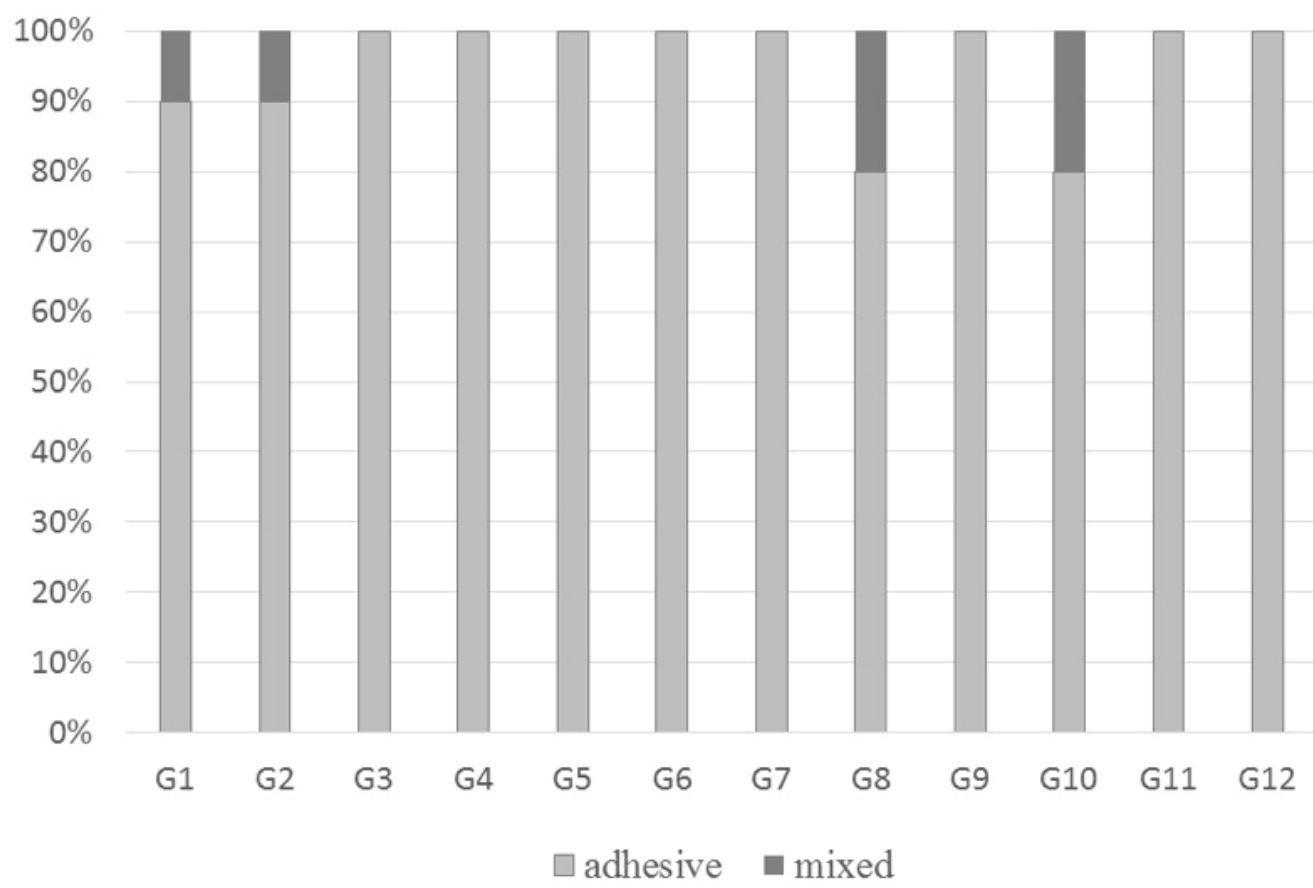

Figure 1 - Failure Mode results of debonded resin cement specimens.

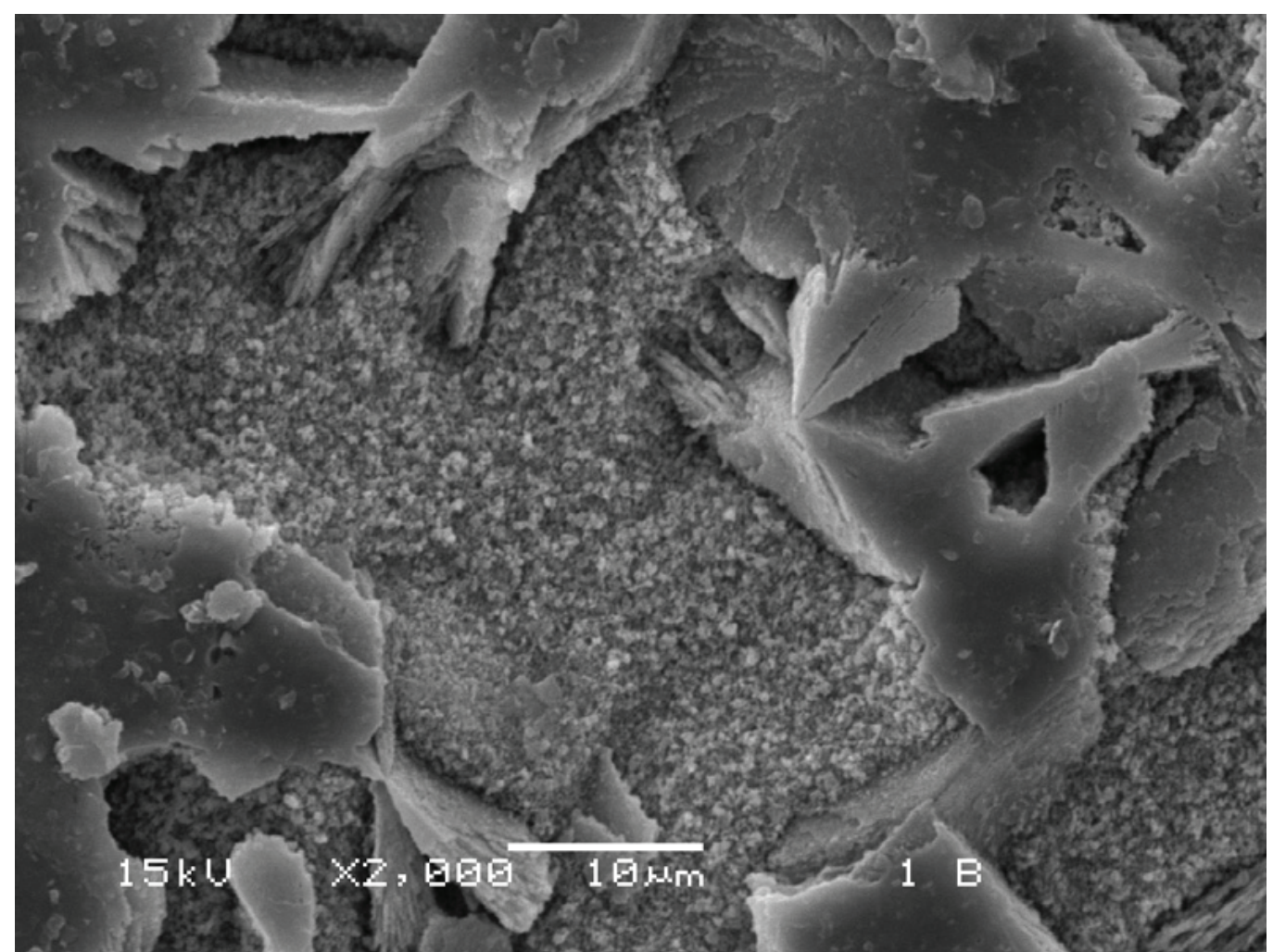

Figure 2 - SEM photomicrographs showing microstructure of ceramics etched for 5\% HF during 20 s. Original magnification 2000x. 


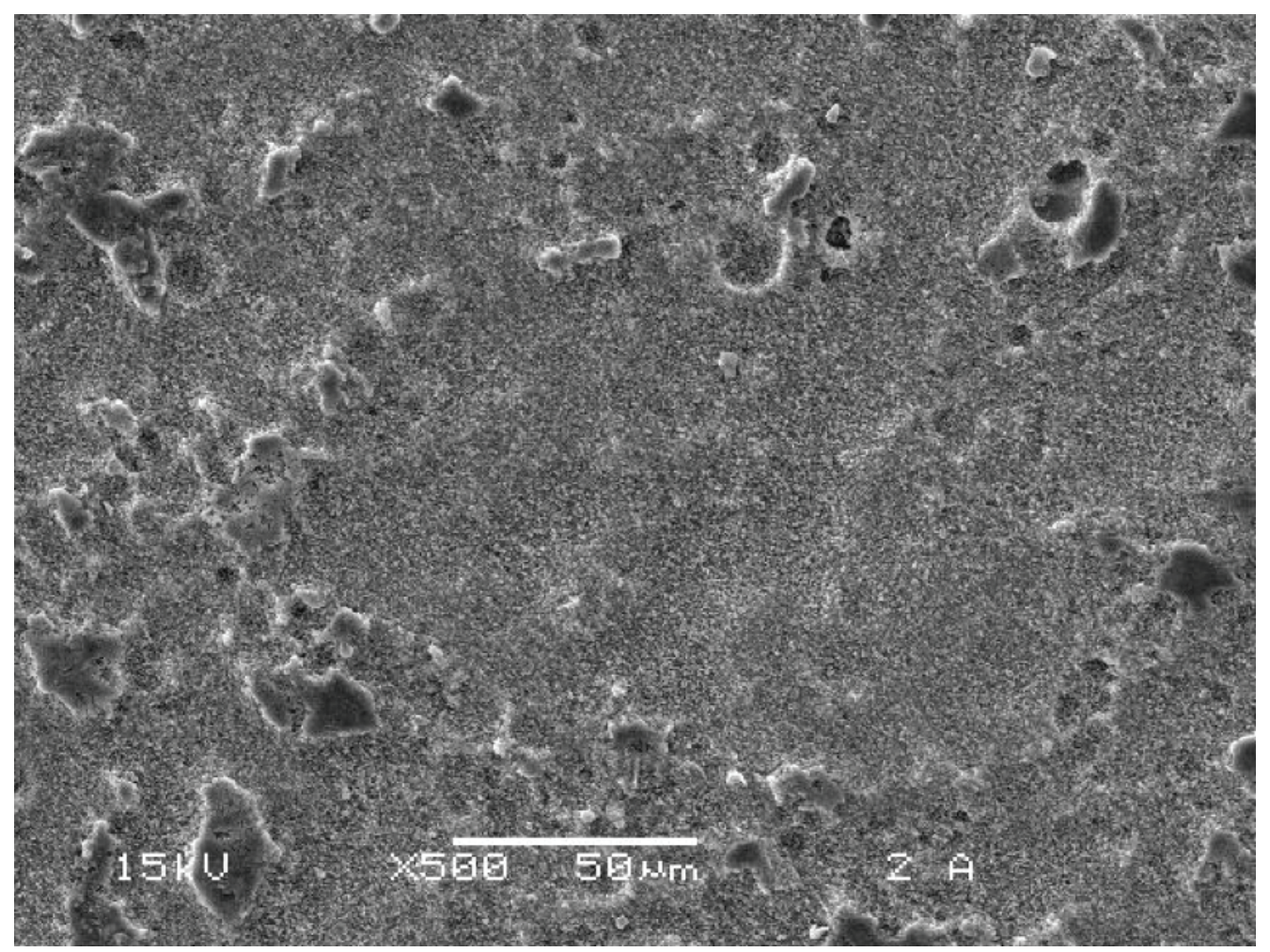

Figure 3 - SEM photomicrographs showing microstructure of ceramics etched for $5 \%$ HF during 30 s. Original magnification $500 x$.

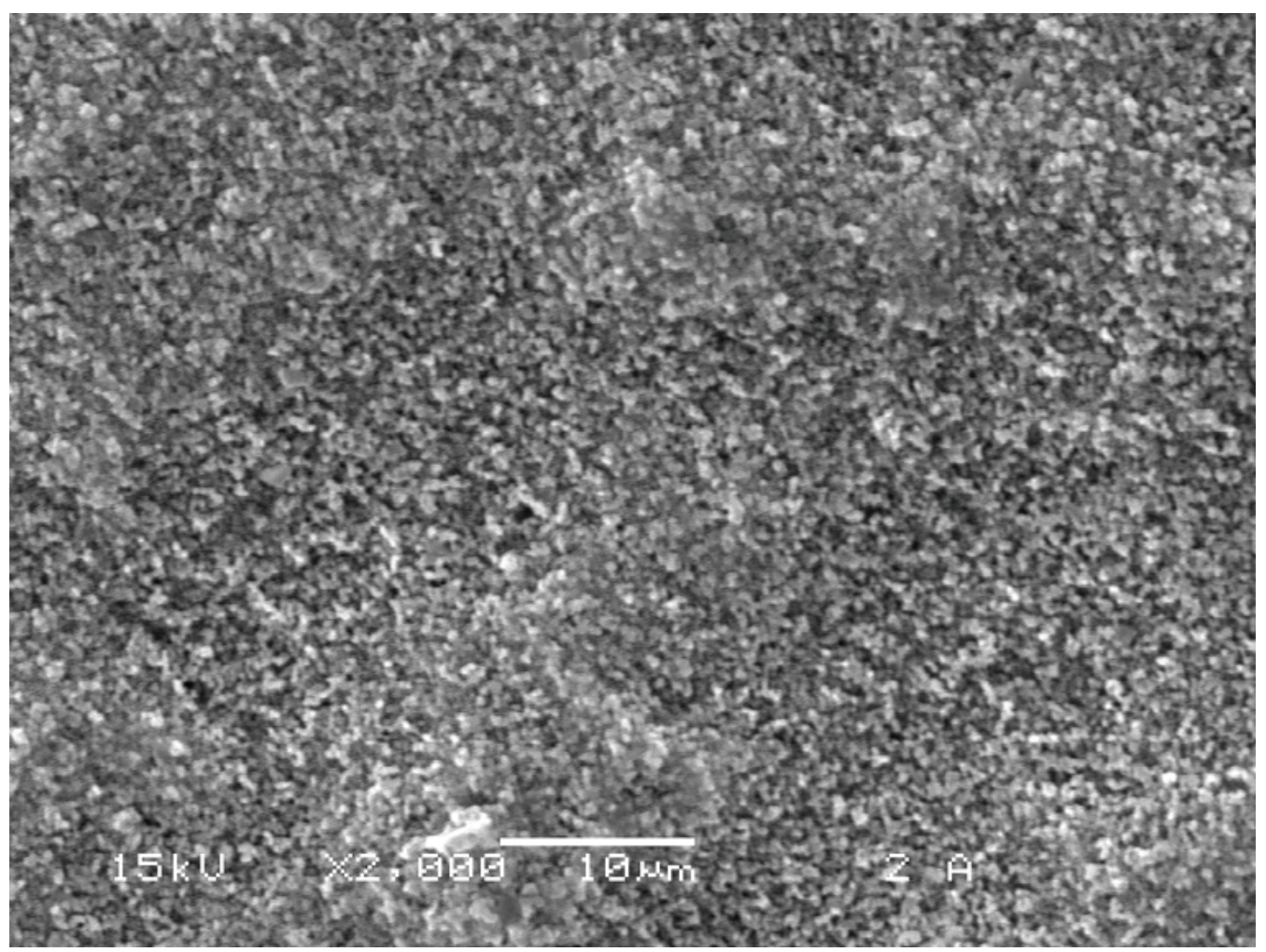

Figure 4 - SEM photomicrographs showing microstructure of ceramics etched for 5\% HF during 30 s. Original magnification 2000x. 


\section{DISCUSSION}

This study assessed the $\mu$ SBS of ZLS ceramic etched for 20 or $30 \mathrm{~s}$, cemented with three different cementation protocols, and thermocycled or no. The null hypothesis was rejected since the three factors affected bond strength.

Given the high glassy phase solubility and quicker dissolution (compared to crystalline phase), HF etching dissolves the matrix and exposures crystals. As result, the created microroughness promoted micromechanical retention to the Rc [14]. Despite the time and acid concentration usually recommended by ceramic manufacturer, 30 s $5 \%$ HF etching resulted in a higher bond strength after thermocycled (Table 4). The aging process promoted an average decrease in bond strength of $\cong 37 \%$ and $11 \%$ for groups etched for 20 and 30 seconds, respectively. This was probably due to the longer etching time, that increased the surface roughness, as well surface free energy [15] and mechanical interlocking and wettability $[13,14]$.

The lower the mechanical interlocking by decreased etching time, the higher the dependence of chemical bond between ceramic and resin cement. Thus, as observed in $20 \mathrm{~s}$ etched groups, the lower bond strength was probably due to the deleterious effect of storage and thermal cycling of adhesive bonding [16,17] among resin cement, silane, and ceramic (Table 4). In turn, the silanecoupling agent interacts with silica matrix [8] promoting chemical bond between ceramic and resin cement. It was expected that silaneresin cement bond would suffer hydrolysis over time, leading to stress and formation of microcracks [8].

As cited above, RXU resin cement and SBU adhesive may be applied in different cementation protocols. SBU is composed by two bifunctional agents: MDP and silane.
The hydroxyl group (-OH) of MDP monomer can chemically react with the hydroxyl group of zirconia oxides [10]. That promotes a stable chemical bond resistant to hydrolytic degradation [18], which, however, may be weakened after thermal cycling [10] but still effective to promote zirconia bonding $[19,20]$. In the $30 \mathrm{~s}$ no-cycled groups (30SRc/ no-C, 30SUaRc/no-C and 30UaRc/no-C), the use of universal adhesive promoted higher bond strength values than silane. It is known that both agents promote chemical bond between ceramic and resin cement. However, monomers with - $\mathrm{OH}$ groups (like MDP) might have hydrolyzed silane, producing silanols and low $\mathrm{pH}$ (water-containing SBU, $\mathrm{pH}=2.7$ ) facilitates the silanol condensation [21]. Thus, the higher bond strength value for 20UaRc/C group may be explained by "silane absence".

Contrary to our results, studies assessing RXU bond strength to a leucite-reinforced ceramic [22] or lithium disilicate ceramic (LDS) $[23,24]$ showed lower bond strength values for SBU compared to the silane separate adhesive application. But differently from LDS, ZLS has zirconia and other metal oxides (like cerium) added to its composition [25]. Thus, MDP would also promote chemical bond to other metal oxides [26] present in the composition and this assumption prompts the investigation of MDP effectiveness. For 30 s etched nocycled groups, the post etching SUa treatment was not different from the other two, which lead us to infer that isolated silane hydrolysis may be compensated by the presence of MDP incorporated to SBU adhesive.

The specimens subjected to 10,000 thermal cycles aging showed a significant decrease of $\mu$ SBS for the three post etching treatments etched for $20 \mathrm{sec}$. This finding is in accordance to Liu et al. (2011), who demonstrated a decrease in bond strength between 0 and 10,000 cycles, although no significant difference has been observed 
between 10,000 and 30,000 cycles for conventional resin cements to self-adhesive cements. Thus, the 10,000 cycles used in our study were enough to evaluate the resin cement [27].

In the present study, adhesive failure was predominant for all groups. Mixed failures were found (20SRc/no-C, 30SRc/ no-C, 30SUaRc/no-C), but with lower incidence. The differences in the failure-mode distribution can be explained by the reduced bond strengths after thermocycling.

Despite the limitation of this in vitro study, findings can be considered as indicators of material clinical capacity. However, some questions remain unanswered and should be assessed. Would MDP monomer presents in SBU adhesive composition able to bond on zirconia scattered in the glass matrix? Would MDP monomer able to bond on other metal oxides in the ceramic composition?

\section{CONCLUSION}

Based on our results we concluded that the bond strength of resin cement to ZLS ceramic was higher when $30 \mathrm{~s}$ of $5 \%$ $\mathrm{HF}$ etching and treatment with universal adhesive, without thermal cycling. Thus, 5\% HF etching for $30 \mathrm{~s}$ and the use of universal adhesive for ZLS ceramic cementation should be recommend.

\section{REFERENCES}

1. Della Bona A, Anusavice KJ. Microstructure, composition, and etching topography of dental ceramics. Int J Prosthodont. 2002 Mar-Apr;15(2):159-67.

2. Lise DP, Van Ende A, De Munck J, Vieira L, Baratieri LN, Van MeerbeekB. Microtensile Bond Strength of Composite Cement to NovelCAD/CAM Materials as a Function of Surface Treatment and Aging. Oper Dent. 2017 Jan/ Feb;42(1):73-81. doi: 10.2341/15-263-L. Epub2016 Sep30.

3. Janda R, Roulet JF, Wulf M, Tiller HJ. A new adhesive technology for allceramics. Dent Mater.2003 Sep;19(6):567-73.

4. Chen JH, Matsumura H, Atsuta M. Effect of different etching periods on the bond strength of a composite resin to a machinable porcelain. JDent. 1998 Jan;26(1):53-8.
5. Zaghloul H, Elkassas DW, Haridy MF.Effect of incorporation of silane in the bonding agent on the repair potential of machinable esthetic blocks. Eur J Dent. 2014 Jan;8(1):44-52. doi: 10.4103/1305-7456.126240.

6. Jardel V, Degrange M, Picard B, Derrien G. Correlation of topography to bond strength of etched ceramic. Int J Prosthodont. 1999 Jan-Feb;12(1):59-64.

7. Debnath S, Wundera SL, McCoolb Jl, Baran GR. Silane treatment effects on glass/resin interfacial shear strengths. Dent Mater.2003 Jul;:19(5):441-8.

8. Matinlinna JP, Lassila LVJ, O'zcan M, Yli-Urpo A, Vallittu PK. An introduction to silanes and their clinical applications in dentistry. Int JProsthodont. 2004 Mar-Apr;17(2):155-64.

9. Aboushelib MN, Sleem D. Microtensile bond strength of lithium disilicate ceramics to resin adhesives. J Adhes Dent. 2014 Dec;16(6):547-52. doi: 10.3290/j.jad.a33249.

10. Yoshida K, Tsuo Y,Atsuta M. Bonding of dual-cured resin cement to zirconia ceramic using phosphate acid ester monomer and zirconate coupler. JBiomed Mater ResB Appl Biomater.2006 Apr;77(1):28-33.

11. Zhao L, Jian YT, Wang XD, Zhao K. Bond strength of primer/cement systems to zirconia subjected to artificial aging. J Prosthet Dent. 2016 Nov;116(5):790-796. doi: 101016/j.prosdent.2016.03.020. Epub2016 Jun 14.

12. Kern M, Wegner SM. Bonding to zirconia ceramic: adhesion methods and their durability. Dent Mater. 1998 Jan;14(1):64-71.

13. Ramakrishnaiah R, Alkheraif AA, Divakar DD, Matinlinna JP, Vallittu PK. The Effect of Hydrofluoric Acid Etching Duration on the Surface Micromorphology, Roughness, and Wettability of Dental Ceramics. Int J Mol Sci. 2016 May 27;17(6). pii:E822 doi:10.3390/ijms17060822.

14. Sato TP,Anami LC, Melo RM, Valandro LF, Bottino MA. Effects of Surface Treatments on the Bond Strength Between Resin Cement and a New Zirconiareinforced Lithium Silicate Ceramic. Oper Dent. 2016 May-Jun;41(3):284-92. doi: 10.2341/14-357-L. Epub2015 Dec 11.

15. Lung CY,Matinlinna JP.Aspects of silane coupling agents and surface conditioning in dentistry: an overview. Dent Mater.2012 May;28(5):467-77. doi: 10.1016/j.dental.2012.02.009. Epub2012 Mar 15.

16. Guarda GB, Correr AB, Gonçalves LS, Costa AR, Borges GA, Sinhoreti MA Correr-Sobrinho L. Effects of surface treatments, thermocycling, and cyclic loading on the bond strength of a resin cement bonded to a lithium disilicate glass ceramic. Oper Dent. 2013 Mar-Apr;38(2):208-17. doi:10.2341/11-076-L. Epub2012Aug 3.

17. Kim JH, Chae SY, Lee Y,Han GJ, Cho BH. Effects of multipurpose, universal adhesives on resin bonding to zirconia ceramic. Oper Dent. 2015 JanFeb;40(1):55-62. doi: 10.2341/13-303-L. Epub2014 Aug1

18. de Carvalho RF, Cotes C, KimparaET,Leite FP,Özcan M. Heat treatment of pre-hydrolyzed silane increases adhesion of phosphate monomer-based resin cement to glass ceramic. Braz Dent J. 2015 Jan-Feb;26(1):44-9. doi: 10.1590/0103-6440201300212.

19. Amaral M,Belli R, Cesar PF, Valandro LF, Petschelt A, Lohbauer U. The potential of novel primers and universal adhesives to bond to zirconia. JDent. 2014 Jan;42(1):90-8. doi: 10.1016/j.jdent.2013.11.004. Epub2013 Nov 15.

20. Yue X, Hou X, Gao J,Bao P,Shen J.Effects of MDP-based primers on shear bond strength between resin cement and zirconia. Exp Ther Med. 2019 May;17(5):3564-3572. doi: 10.3892/etm.2019.7382. Epub2019 Mar 13.

21. Dimitriadi M, Panagiotopoulou A, Pelecanou M, Yannakopoulou K, Eliades G. Stability and reactivity of $\mathrm{Y}$-MPTMS silane in some commercial primer and adhesive formulations. Dent Mater. 2018 Aug;34(8):1089-1101. doi: 10.1016/j. dental.2018.05.006. Epub2018 May 18. 
22. Kim RJ, Woo JS, Lee IB, Yi YA, Hwang JY, Seo DG. Performance of universal adhesives on bonding to leucite-reinforced ceramic. Biomater Res. 2015 May 22;19:11. doi: 10.1186/s40824-015-0035-1. eCollection 2015.

23. Kalavacharla VK, Lawson NC, Ramp LC, Burgess JO. Influence of Etching Protocol and Silane Treatment with a Universal Adhesive on Lithium Disilicate Bond Strength. Oper Dent. 2015 Jul-Aug;40(4):372-8. doi:10.2341/14-116-L. Epub 2014Dec 23.

24. Makishi P,André CB, Silva JL, Bacelar-Sá R, Correr-Sobrinho L, Giannini M. Effect of Storage Time on Bond Strength Performance of Multimode Adhesives to Indirect Resin Composite and Lithium Disilicate Glass Ceramic. Oper Dent. 2016 Sep-0ct;41(5):541-551. Epub 2016 Jul 5.
25. Elsaka SE, Elnaghy AM. Mechanical properties of zirconia reinforced lithium silicate glass-ceramic. Dent Mater. 2016 Jul;32(7):908-14. doi:10.1016/j. dental.2016.03.013. Epub 2016 Apr 14.

26. WolfartM, Lehmann F, WolfartS, Kern M. Durability of the resin bond strength to zirconia ceramic after using different surface conditioning methods. Dent Mater.2007 Jan;23(1):45-50. Epub 2006 Jan 20.

27. Liu Q, Meng X, Yoshida K, Luo X. Bond degradation behavior of self-adhesive cement and conventional resin cements bonded to silanized ceramic. J Prosthet Dent. 2011Mar;105(3):177-84. doi:10.1016/S0022-3913(11)60026-7.

\section{Kevelin Poliana Palma Rigo Thiesen}

(Corresponding address)

Rua Universitária, 2069 Cascavel - PR; Brazil - zip code 85.819-110.

Date submitted: 2019 Jun 30

E-mail:poly_rpk@hotmail.com 